occurred since in nuclear physics. Further Nobel prizes for doctors working on immunity were those received in 1960 by Sir Macfarlane Burnet (35) and Sir Peter Medawar for their work in acquired immunological tolerance to tissue transplants. The 1913 medicine prize was awarded to Charles Robert Richet, 1850-1935, the French physiologist, for his work on serology and serum treatment. Together with the French bacteriologist Paul Jones Portier, 18751962, he discovered anaphylactic shock and coined the word "anaphylaxis" for certain serum reactions as they appeared to be the opposite of prophylaxis (36). George Bernard Shaw, 1856-1950, who received the literature prize in 1925 (37), published his play The Doctor's Dilemma in 1906 in Berlin. This has an interesting medical connection. The leading character-Sir Colenso Ridgeon - was based on his friend Sir Almroth Wright, 1861-1947, the main protagonist of the theory of opsonins in immunity and also typhoid vaccination of soldiers in the Boer war. Sir Almroth Wright appears again in literature when his opsonin theories are challenged by Max Gottlieb in Sinclair Lewis's novel Arrowsmith.

Jacques Lucien Monod (38), 1910-76, the French molecular biologist and director of the Pasteur Institute (39), 1971-6, was a joint prize winner in 1965 for medicine and physiology. Pasteur (40), 1822-95, appears on many stamps and died the year before Nobel. Ernest Ruska died in June 1988, aged 81, and in 1986 he shared a belated Nobel prize for physics for his invention half a century earlier of an electron microscope in West Berlin. In 1931 he had developed an instrument that focussed electron beams on objects too small to be detected by light, thus allowing the details of cell structure, the shape of viruses, etc, to be observed.

The Frenchman Albert Camus (41), 1913-60, won the literature prize in 1957 and he has an interesting connection with medicine. His book The Plague was first published in June 1947. Like Daniel Defoe's Fournal of the Plague Year, which first appeared in 1722 (three years after he published Robinson Crusoe (42), it is virtually plotless. It seems to recount the daily reactions of a group of men to the horrors of bubonic and pneumonic plague, though some people regard it as an allegory about France under the Nazi occupation. (The plague bacillus was isolated in 1894 by Alexandre Emil John Yersin (43), 1863-1943, the Swiss bacteriologist, and in 1895 he prepared a serum to combat the disease. Earlier in 1889-90, while working in the Pasteur Institute with Roux, 1853-1933, on diphtheria serum these two discovered the existence of diphtheria toxin.)

\section{Ambassadors of achievement}

This is only a sample of some of the hundred or more doctors who have received Nobel prizes during the past 87 years. When first awarded at the beginning of the century the prize money seemed fantastic. Even today it is still worth well over $£ 50000$. Nobel indicated in the wording of the trust that the medicine or physiology prize was to recognise both laboratory and clinical work. By the very nature of medical research, few working clinicians have featured in recent years. Nevertheless, the judgments of the Karolinska Institute over the years have stood the test of time. Regrettably, although many British doctors and scientists have received Nobel prizes for medicine, none have so far had a specific stamp issued by the British Post Office to commemorate the event. The closest might be the British discoveries issue of 1978 depicting penicillin mould (44), though other countries portrayed Sir Alexander Fleming (45), who was awarded the medicine prize in 1945, to commemorate the 50th anniversary of his discovery. Surely this is a grave oversight that should be rectified without delay. After all Sir Winston Churchill (46), who received the Nobel prize for literature in 1953, appears on British stamps in 1965 and 1974 in addition to numerous issues world wide. Stamps are one of the best ambassadors we have to show the world our nation's virtues, and they could be used to a much greater extent to publicise the achievements of our Nobel prizewinners.

1 Dunlop JM. Skullduggery. Stamp Collecting 1975;123:1223-5

2 Dunlop JM. Infectious diseases--can we stamp them out? In: Public health matters. Proceedings of the conference commemorating the centenary of the Society of Community Medicine. London: Society of Community Medicine, 1988.

\title{
Caput Medusae in medicine and art
}

\author{
Richard H R Park, Maureen P Park
}

\begin{abstract}
The Gorgon Medusa had serpents for hair, huge teeth, a protruding tongue, and altogether so ugly a face that all who gazed at it were petrified with fright.
\end{abstract}

The many antique vases, paintings, and sculptures that depict the Medusa's viperous head testify to her powerful inspiration for artists since classical times. Florentines in the Renaissance likened their city's struggle for freedom against invading forces with Perseus's victory over the Medusa. Armourers decorated parade shields with her image because of her power to turn her enemies to stone. To philosophers her head symbolised the triumph of man's reason over his senses.' And yet her influence has not been restricted to the arts. The Medusa has achieved immortality in that most academic of publicationsthe medical textbook.

Despite the lack of an adolescent upbringing in the classics the modern medical student readily identifies the clinical sign of tortuous, dilated, periumbilical veins secondary to portal hypertension as "caput Medusae." But although so many medical students are aware of this rare clinical sign, few will encounter caput Medusae in their clinical careers.

How many students know its origin? This ignorance is not limited to undergraduates. Authors of major postgraduate medical textbooks on liver disease and on clinical signs in medicine and surgery-including Hamilton Bailey and his successors ${ }^{3}$ - fail to identify the origin of this sign. Several medical dictionaries attribute caput Medusae to the Parisian pathologist Jean Cruveilhier, 1791-1874 (fig 1), and the German pathologist Paul Clemens Von Baumgarten, 1791-1873. In Stedman's Medical Dictionary caput Medusae is defined as "Cruveilhier's sign; varicose veins radiating from the umbilicus, seen in the Cruveilhier-Baumgarten syndrome," which is "cirrhosis of the liver with patent umbilical or periumbilical veins and varicose periumbilical veins." The Cruveilhier-Baumgarten murmur is "the venous 

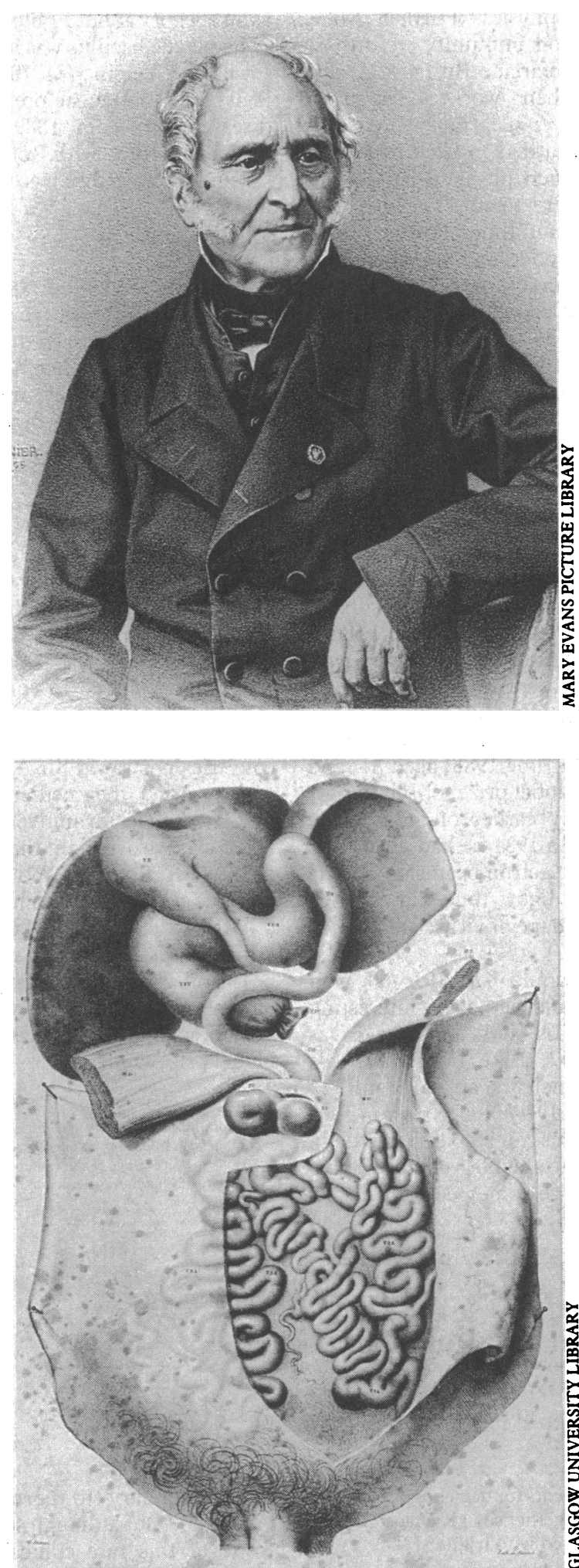

hum heard over collateral veins, connecting the portal and caval venous systems, on the abdominal wall."4

In his Anatomie Pathologique du Corps Humain Cruveilhier describes the abdominal appearances of dilated periumbilical veins of a 48 year old ex-soldier, Joseph Bressoles. ${ }^{5}$ It seems that Bressoles was left for dead after a rifle injury to his abdomen sustained while fighting the Hungarians in 1813 . He required six months' treatment in hospital. Bressoles blamed his long journey home for the formation of the dilated umbilical veins. He died in 1833 and Cruveilhier's drawing of the abdominal findings at necropsy is quite outstanding (fig 2). The exact cause of Bressoles's portal hypertension is not clear from the text. Cruveilhier documented that his liver was small but that his spleen was "almost as bulky as the liver." It is likely that he had cirrhosis with portal hypertension, although Cruveilhier thought that the underlying problem was congenital in origin. Later in the chapter Cruveilhier compares the appearances of the periumbilical veins to that of Medusa's head-"la tumer formée par cette réunion de veines dilatées représentait la tête de Méduse dont parle M A Séverin."

Cruveilhier attributed the authorship of this clinical sign to Marco Aurelio Severino, 1580-1656, a Neapolitan surgeon (fig 3). Born in Calabria, the scn of a prominent lawyer, Severino trained initially in a Jesuit college but later studied mathematics, chemical philosophy, and medicine at the University of Naples. ${ }^{6}$ In 1609 he started his surgical training in Naples and six years later he was appointed professor of surgery and anatomy. In 1632 he published De Recondita Abscessum Natura, the first textbook of surgical pathology to include illustrations of lesions with the text." In the chapter "Of the weakened veins of the stomach" he describes the appearance of dilated periumbilical veins:

Nihilominis visae mihi per hypogastris summa varicos mirum in modum implicitae, atque distentae, ita, ut venter quidem appareret Medusae caput. (Nevertheless I have seen through the hypogastrium the greatest varicose of a wonderful size, entangled and also distended, so that the stomach truly resembles the head of the Medusa.)

Severino's description is so vivid that caput Medusae has become standard teaching in medical textbooks.

Is it possible that Severino's observations were inspired by a particular artistic source? Images of the Medusa were widespread throughout Italy during the sixteenth and seventeenth centuries. Benvenuto Cellini's famous statue Perseus (1545-54) in Florence shows the Greek hero triumphant, standing on the Gorgon's decapitated body and holding up her hideous head. One of the most remarkable images of the Medusa is by a contemporary of Severino, the notorious Italian painter Michelangelo Merisi da Caravaggio, 1573-1610. The Head of the Medusa in the Uffizi is a circular painting on canvas mounted on a convex wooden shield (fig 4). Combining drama with the unexpected-those elements so characteristic of baroque art-Caravaggio presents us with a self portrait, wide eyed and open mouthed, as if petrified

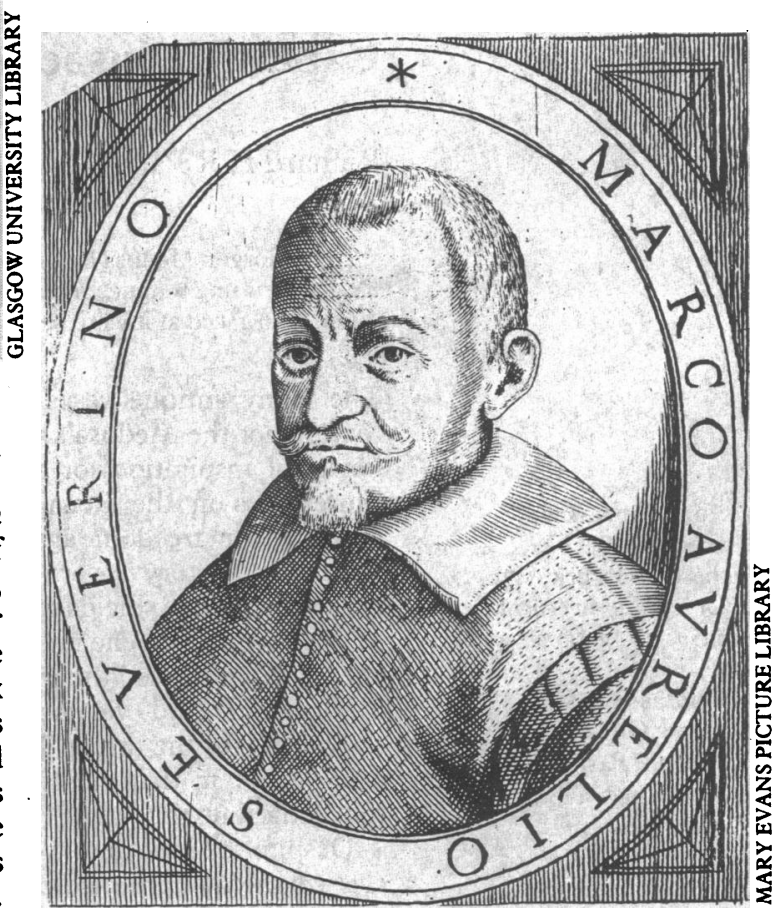

FIG 3-Marco Aurelio Severino 


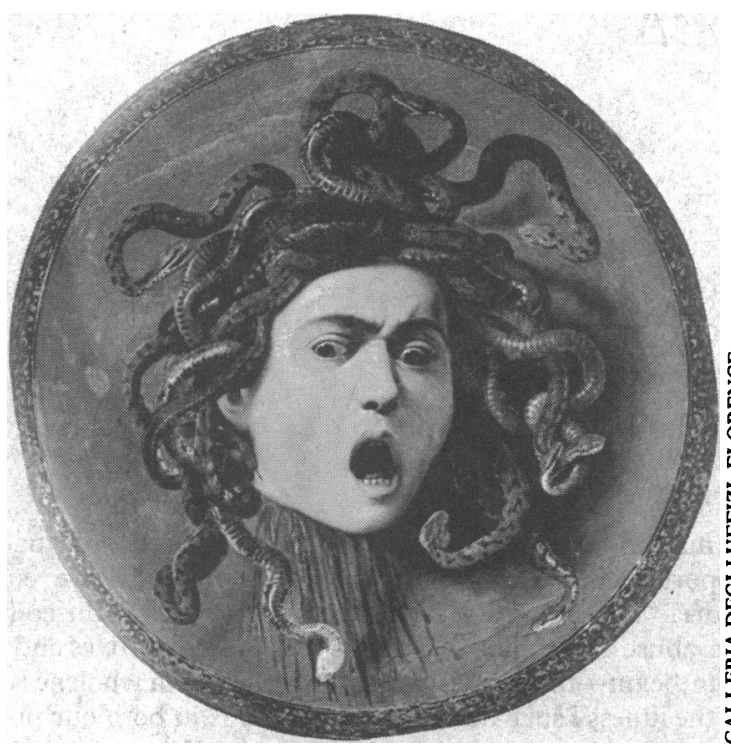

FIG 4-"The Head of the Medusa" by Caravaggio

by his own appearance, with his hair transformed into a writhing mass of snakes. The painting, which dates to the late 1590s, was commissioned by Caravaggio's Roman patron Cardinal del Monte, who sent it as a wedding gift to the Medici Grand Duke of Tuscany in 1608.

Two years earlier Caravaggio had fled Rome after stabbing his opponent during a game of tennis, and although he spent the last four years of his life on the run from the authorities, he was able to complete major commissions in Naples, Malta, and Sicily. At the height of his fame, Caravaggio reached Naples in 1609, when Severino was beginning his surgical training there. As Severino was to become a central figure in the cultural circles of Naples it is possible that he knew Caravaggio by reputation and would have had the opportunity to see his paintings in Naples, Rome, and Florence.

Although the source of inspiration for Severino's term caput Medusae may never be known, it is he and not Cruveilhier who deserves eponymous fame for the clinical sign of caput Medusae.

We thank Miss Ruth Berry for expert secretarial assistance; the director, Galleria degli Uffizi, Florence; Mr P K Escreet and $\mathrm{Mr} \mathrm{H} \mathrm{J}$ Heaney, Glasgow University Library; Miss Diane Lindsay, Glasgow Royal Infirmary Library; and $\mathrm{Mr} \mathrm{A}$ Rodger, librarian, Royal College of Physicians and Surgeons of Glasgow.

1 Graves R. Greek myths. London: Cassell, 1981.

2 Friedlaender W. Caravaggio studies. New Jersey: Princeton University Press, 1955

3 Basiley H. Demonstration of physical signs in clinical surgery. Bristol: John Wright, 1973.

4 Stedman's medical dictionary. Baltimore: Williams and Wilkins, 1976.

5 Cruveilhier J. Anatomie pathologique du corps humain. Vol 1. Paris: Baillière, 1829.

6 Schmitt CB, Webster C. Harvey and M A Severino. A neglected medical relationship. Bulletin of the History of Medicine 1971;45:49-75.

7 Severino MA. De recondita abscessum natura. Book III. 2nd ed. Frankfurt, 1643.

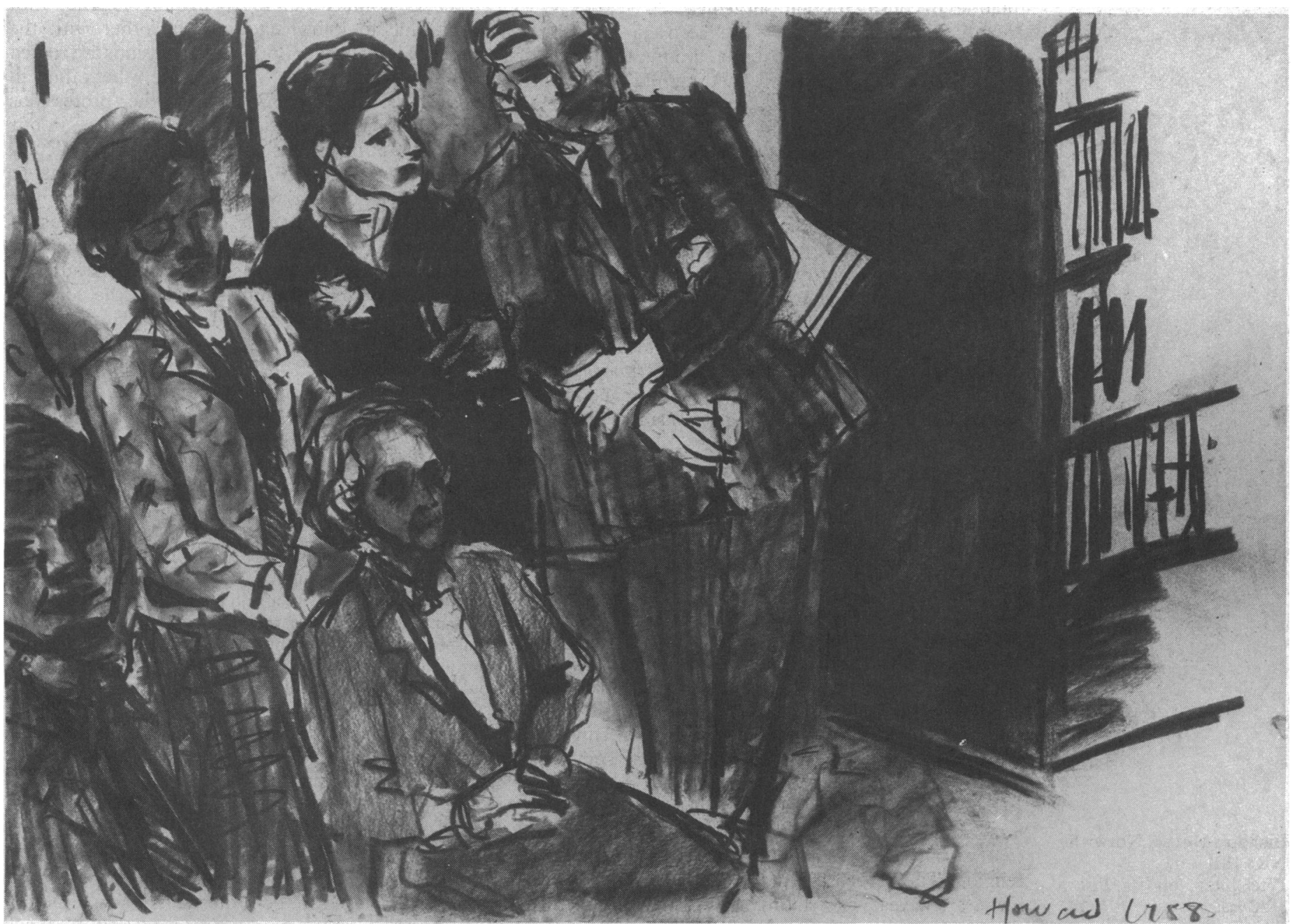

